\title{
Trajectories of Victimization and Bullying at University: Prevention for a Healthy and Sustainable Educational Environment
}

\author{
José Gómez-Galán ${ }^{1,2, *(\mathbb{D})}$, Cristina Lázaro-Pérez ${ }^{3, *(\mathbb{D})}$ and José Ángel Martínez-López ${ }^{4}$ (D) \\ 1 Department of Education, University of Extremadura, Avenida de Elvas, 06006 Badajoz, Spain \\ 2 Cupey Campus, Ana G. Méndez University, San Juan, PR 00926, USA \\ 3 Department of Sociology, University of Murcia, Campus Universitario, 30100 Murcia, Spain \\ 4 Department of Social Work and Social Services, University of Murcia, Avenida Teniente Flomesta, \\ 30003 Murcia, Spain; jaml@um.es \\ * Correspondence: jogomez@uagm.edu (J.G.-G.); cristina.lazaro2@um.es (C.L.-P.); \\ Tel.: +1-787-766-1717 (J.G.-G.); +34-868-883-000 (C.L.-P.)
}

Citation: Gómez-Galán, J.; Lázaro-Pérez, C.; Martínez-López, J.Á. Trajectories of Victimization and Bullying at University: Prevention for a Healthy and Sustainable Educational Environment. Sustainability 2021, 13, 3426. https://doi.org/10.3390/su13063426

Academic Editor: Walery Zukow

Received: 8 February 2021

Accepted: 15 March 2021

Published: 19 March 2021

Publisher's Note: MDPI stays neutral with regard to jurisdictional claims in published maps and institutional affiliations.

Copyright: (c) 2021 by the authors. Licensee MDPI, Basel, Switzerland. This article is an open access article distributed under the terms and conditions of the Creative Commons Attribution (CC BY) license (https:/ / creativecommons.org/licenses/by/ $4.0 /)$.

\begin{abstract}
The bullying phenomenon is both an uncomfortable reality and a serious social problem for educational community institutions. Its presence is incompatible with a healthy and sustainable education environment. The educational, psychological, and social consequences of bullying transcend the personal sphere and reach the family and work environment in adulthood. Traditionally, bullying has been studied in the compulsory educational stages. However, at present, this problem is also being addressed in higher education. The present research, which is of a transversal nature, aims to explore bullying in the Spanish university setting, along with its typology, scope, and predictive factors, from both socio-demographic and family perspectives. In this sense, we set ourselves the following objectives: (GO1) to see if university students are exposed to bullying, as well as to identify the profiles of the subjects of bullying from three dimensions (physical, relational, and verbal victimization) and (GO2) to determine whether there are trajectories of bullying in university students from the compulsory education stage to the present. Based on a descriptive quantitative methodology, this study was conducted in 10 Spanish universities. The research's major results show that the persistence of bullying in university classrooms is of a relational and verbal nature, but is not physical. Victimization occurs mainly in women who carry out studies linked to social and legal sciences or art and the humanities. Additionally, it is observed that a spiral of relational violence is produced, perpetuating this type of aggression over time. Among other predictive factors in university students is that they have suffered relational violence during their compulsory education. These data should alert educational and health institutions about the persistence of bullying in university students to prevent it and to facilitate its early detection and treatment to eradicate this problem from higher education classrooms.
\end{abstract}

Keywords: bullying; university students; victimization; psychological consequences; social problems; hazing; reproduction of bullying

\section{Introduction}

The harassment and mistreatment of colleagues by students in the educational field have both been significantly addressed in educational institutions for several decades. Today, it is a challenge included in the plans of coexistence of schools. In 2009, the European Commission established the Strategic Framework for European Cooperation in Education and Training [1]. Through this instrument, Spain committed itself to take part in improving educational policies by building the Strategic Plan for Coexistence in Schools, intending to make Spanish schools free of violence and for them to be safe, thus following one objective of the European Commission: the promotion of equity, social cohesion, and active citizenship. 
In this sense, Spanish legislation intends to make effective, through the State Observatory of School Coexistence (Observatorio Estatal de la Convivencia Escolar), created by Royal Decree (Real Decreto) 275/2007 of February 23, the mentioned principles of equity; equality of rights and opportunities; prevention of any violence within the scope of gender, personal, familiar, and social; inclusive education and non-discrimination; the prevention of conflicts and the peaceful resolution of the same; and, especially in the educational scope, the prevention of school harassment.

The World Health Organization (WHO) defines violence [2] as "The deliberate use of physical force or power, whether threatened or actual, against oneself, another person or a group or community, that results in, or is likely to result in, injury, death, psychological harm, developmental disorders or deprivation." Harassment has therefore become such a public health problem [3] that coordination between different social actors (teachers, primary care physicians, psychiatrists, etc.) is necessary to address it and to disrupt it.

This power over other people also occurs, in a worrying way, in the educational field and is mostly executed by peer groups. According to several authors [4-8], the aggressors manifest antisocial behaviors characterized by a total lack of empathy and seek to impose themselves on others. Remedying this behavior entails addressing actions in the school context to promote self-esteem, social skills, and emotional intelligence. The aim is for aggressors to focus their self-control needs on healthy behaviors.

In this school context, the concept of bullying arises, defined by Smith [8] as a relationship between several people where it is practiced systematically and repetitively, where abuse and power are exercised over others daily [9]. Most disturbingly, violent acts are intentional and intended to cause harm $[10,11]$, both physically and psychologically, in a relationship that can be considered asymmetrical [12]. These acts include social exclusion as an aggressive aspect of the relationship [13]. This type of violence turns into harassment when victimization occurs [14-16], and this victimization may be physical, relational, and/or verbal [17]. UNESCO [18] has noted that bullying has a significant negative effect on children's mental health, quality of life, and academic performance. Those who are bullied are nearly three times more likely to feel uncomfortable at school and more than twice as likely to be absent from class than those who are not bullied. They have poorer educational outcomes than their peers and are also more likely to drop out of formal education after high school.

The psychological, relational, and behavioral consequences $[19,20]$ that this type of violent behavior generates in the long and short term are severe [21]. Isolation is one of the most prominent of these consequences [22-25]. Another of the most extreme consequences is the change of role experienced by some victims, who become aggressors themselves [26-30].

Childhood bullying has generated mental health problems, such as depression and anxiety, in young adults, when they are victims of such behavior [3]. It is vital not to forget one terrible repercussion that, for some adolescents and young people lacking social skills and personal resources, can occur: suicide. Many articles have dealt with this phenomenon, which, in recent years, has become an escape route for young people, especially after being victims of bullying [31-45].

Currently, in the era of new technologies, the problem has increased due to what is known as cyberbullying; through the Internet, computer systems, social networks, and mobile messaging [46], forms of harassment and abuse are expanding and are also constantly changing. Regarding the consequences of cyberbullying, it has been shown that victims are at increased risk of suffering from anxiety, stress, depression, fear, sleep disorders, suicidal ideation, irritability, and somatization, among other things [47]. On the other hand, cyber aggressors generally present, among other things, an absence of empathy, aggressive behavior, school absenteeism, increased consumption of alcohol and drugs, and a dependence on technology [48].

One aspect to highlight is that this type of disruptive behavior involves more agents, victims, aggressors, and observers [49-52]. There are many more in the harassment than the 
former, and they may adopt three different behaviors: avoidance, harassment, or prosocial behavior [52-55].

Regarding the latter, although little information is available about the predictors of prosocial behavior [56], it is essential to reduce harassment, maintain friendly relationships, and socially redirect victims [57-61]. This seems to be a contradiction in terms that this type of behavior occurs more frequently in the educational sphere, a place dedicated to the search for knowledge and awareness and where the aggressors have more comfortable contact with their potential victims.

Bullying is a behavior that transcends the sphere of primary and secondary school because it occurs throughout all educational stages, including university [62-69]. It is necessary to address this phenomenon beyond the early academic stage because it is a repeated behavior in and with older students that could even constitute a crime. In this analysis, it is necessary to specify the intensity and characteristics of the bullying.

Moreover, bullying in higher education institutions is the least studied of all the educational stages. It can even be considered an under-researched issue [70-74]. The reasons for this striking fact are under discussion. However, some works, such as that of Coleyshaw [72], argue that institutions, academic disciplines, and government and business policymakers may be driven by selfish interests seeking to protect power positions. It may also be the case that the study of bullying at the university level has been less prevalent because it is less intense than that in the critical education stages.

In any case, and although it is widespread throughout the world, this phenomenon does not respond to the same patterns. Depending on the country, culture, etc., it can take different forms and intensity [75-82]. Regardless, it can be understood for those students who suffer from it as a dramatic situation that foremost affects mental health and wellbeing $[73,74]$. It is a problem with a significant impact. Recent research by Harrison [74] identified themes that make college bullying distinct from child and adolescent bullying: power imbalances; bullying tactics; bullying for personal or social gain; and justifications and minimizations for non-intervention (bystander intervention).

Besides traditional forms of bullying of a physical or psychological nature in a faceto-face setting, as occurs in other educational stages, cyberbullying also occurs at university [83-86]. The effects can be similar and very harmful, and despite being widespread on university campuses, it is not easy to detect [87]. There are also studies of university bullying focused on its incidence and differences between groups of students who experience marginalization. Studies have examined whether it is more intense [74,88-91]. As can be seen, this is an open problem that requires much more research than has been done so far, and that will allow us to gain more excellent knowledge to carry out preventive actions.

Indeed, we still have much to learn about this phenomenon. In the university world, bullying has also been related to hazing, and a lack of moral commitment has been identified as one of its bases [92]. It also has an essential connection with mobbing [92-95]. Precisely, it is known as bullying at work [96,97]. It can be defined mainly, from among a set of proposals, as psychological harassment at work [98,99]. This form of violence in the workplace is a severe problem that is widespread throughout the world and has severe consequences for the person being harassed, from job loss to the suffering of major psychological disorders. Mobbing is a dehumanizing and pathologizing reality [100] and, like school bullying, it is a complex problem with common roots [101]. These include power relations [102], which occur in both spheres (educational and work). Prevention and intervention programs are increasingly necessary to address these scenarios involving acute health risks [92,103].

In this context, bullying is especially relevant because we must not forget that it is produced in the educational environment, where its consequences can have the most significant impact [104-106]. That this type of disruptive behavior continues to occur in the 21st century, after decades of trying to improve school behavior and coexistence, makes it necessary to consider the consequences it may have for future generations. Not only are these disruptive behaviors not disappearing, despite the educational community's efforts, 
but they continue to increase because of novel forms of harassment. In this sense, it is necessary to assess the state of the matter to find the current causes that provoke this behavior so that academic and social authorities can work together to find a prompt solution.

To this end, this research was designed in January 2020. The aim is to deepen our knowledge of the phenomenon of bullying at the university stage, oriented mainly toward establishing the existence or not of "the spiral of violence". Some universities were selected to introduce improvements in the initial proposal and replicate the studies among all Spanish universities.

\section{Materials and Methods}

\subsection{Objectives}

The objective of this research is twofold: firstly (PO1), to know if there is bullying among university students and to identify these subjects' profiles from three dimensions: physical, relational, and verbal victimization; secondly (PO2), to determine whether there are trajectories of bullying in university students from the compulsory education stage (up to 16 years) to the present, where they are studying.

Given that bullying is a social problem with many aspects and systems involved, we wonder if the appearance and development of it in the university environment are conditioned by the participants' socio-demographic variables or by their socio-family context. Also, where appropriate, if associated with the educational environment, does it transit through the entire academic stage?

\subsection{Study Design and Sample}

To achieve the above objectives, the School Victimization Scale designed by the Lisis Team (Equipo Lisis) [17] was used, taking as a reference Mynard and Joseph's Multidimensional Victimization Scale [107] and the Crick and Grotpeter Social Experience Questionnaire [108]. Although this questionnaire was initially designed to be completed by school children, it was later validated for completion by university students [109], who formed the basis of our study. The questionnaire allows information to be obtained on victimization in the respondents' compulsory and current (university) educational stages, thus allowing trajectories of victimization to be traced.

This questionnaire comprises 22 items that address three types of victimization in its first 20 questions: physical, relational, and verbal. The items' answers are expressed through a four-category Likert scale: $1=$ Never, $2=$ Rarely, $3=$ Often, and $4=$ Always. Besides this, the questionnaire incorporates two questions related to identifying the aggressor and the frequency of victimization. Verbal victimization refers to harassment, humiliation, or provocation; relational victimization manifests as defamation, social exclusion, or denigration; and physical victimization is threats, physical harm, or theft [17]. Student participation was voluntary. The header of the survey explained the study's objectives and the subsequent confidential treatment of the data, which would be carried out under current data protection regulations, considering that the questionnaire's voluntary completion is equivalent to consent.

The exploratory study was conducted in a cross section between 15 and 30 May 2020 through a random sample of convenience-not representative-composed of 264 university students from 10 Spanish universities: University of Murcia, University of Extremadura, University Pablo Olavide, University of Granada, University of Cadiz, University of Jaen, Polytechnic University of Cartagena, UNED, University of Valencia, and University of Valladolid. As this was an exploratory study, it did not seek to be representative. This can be done later, employing a new investigation based on the results of the present one, especially results concerning the spiral of relational violence. For this purpose, a much larger and applied sample will be used in all Spanish universities (which total 50 across public and private sectors, with over 250,000 students currently enrolled).

This research design, prepared at the beginning of 2020 and with fieldwork planned for May 2020, was finally conditioned by the difficulties derived from the COVID-19 
pandemic and the declaration of a state of alarm that required the suspension of in-person teaching activity. As a result, the sample was smaller than initially planned. However, since these are questions about one's academic career and its past in the educational context, this circumstance did not influence the answers, only the sample, which maintained the study's initial consistency.

This study followed the protocols and guidelines of the Ethics Committees of the universities to which the members of the research team belong. Although descriptive studies in Spain do not require approval (only experimental studies), the Codes of Good Practice for Research on Human Beings were signed. The study was registered (code $\mathrm{N}^{\mathrm{o}}$ REPRINT-PEM-07) by the research team (the authors).

All participants gave their informed consent under the Declaration of Helsinki. As a confidential, anonymous online questionnaire, the instrument used to collect the information was transmitted through a tool used by the University of Murcia based on a telematics data collection system. It uses advanced software that allows the design of totally personalized surveys adapted to any device (responsive system). The participants have to accept the ethical conditions and consent before accessing the questionnaire and sending their answers.

Of the participants, $68.9 \%$ were women, and the remaining $31.1 \%$ were men. Concerning the branch of knowledge of the degree, 31.3\% were from Arts and Humanities, 10.1\% from Sciences, $15.1 \%$ from Health Sciences, 49.6\% from Social and Legal Sciences, and 4.7\% from Engineering and Architecture.

This research's dependent variable was university students' victimization in each of its subscales: physical, relational, and verbal. Violence was considered to exist in each of the dimensions if the average value obtained in each of them was $\geq 3$ ("Often").

The exploitation of results was structured in three steps through the SPSS ${ }^{\circledR}$ v.24 program. First, a descriptive analysis of the profile of young university students who are currently victims of bullying was carried out according to the dimensions (verbal, relational, and physical). Then, a cross-table analysis was made from the dependent variables, considering their chi-square significance level $(p<0.005)$. Thirdly, a binary logistic regression was performed to predict the variables that determine university students' victimization. The independent variables used were (1) sex (ref. male/female); (2) age (continuous); (3) branch of knowledge of their degree (ref. Arts and Humanities/Sciences/Health Sciences/Social and Legal Sciences/Engineering and Architecture); (4) mother's maximum level of studies (ref. below primary stage/superior to the primary stage); (5) father's maximum level of studies (ref. below primary stage/superior to the primary stage), (6) mother's relationship with the labor market (ref. employed/unemployed-inactive); (7) father's relationship with the labor market (ref. employed/unemployed-inactive); (8) physical victimization at school (ref. no/yes); (9) relational victimization at school (ref. no/yes); and (10) verbal victimization at school (no/yes).

The method used in the binary logistic regression was the forward model. It automatically reevaluates the coefficients and their significance, eliminating all those variables that are not statistically significant [110-112].

\section{Results}

A descriptive analysis of the sample's composition (Table 1) was carried out in a first approach to the social phenomenon. For victimization in the universities, we observed no physical violence among any university students $(0 \%)$. Relational violence and verbal violence were observed, with prevalence of $8.7 \%$ and $4.2 \%$, respectively. If we consider bullying in the compulsory education stage, the following results were observed: $10.3 \%$ suffered physical violence, $37.5 \%$ suffered relational violence, and $44.3 \%$ suffered verbal violence. 
Table 1. Victimization at universities and in the compulsory education stage (in percentages).

\begin{tabular}{ccc}
\hline University Victimization & Yes & No \\
\hline Physical Violence & 0 & 100 \\
Relational Violence & 8.7 & 91.3 \\
Verbal Violence & 4.2 & 95.8 \\
\hline School Victimization & 10.3 & 89.7 \\
\hline Physical Violence & 8.7 & 91.3 \\
Relational Violence & 37.5 & 62.5 \\
Verbal Violence & 44.3 & 55.7 \\
\hline
\end{tabular}

To better approximate the profile of university students who are victims of relational and verbal bullying, an analysis of crossed tables was made. The dependent variable was the fact of suffering these types of violence. Relational victimization (see Table 2) showed a significant difference according to sex, with women representing $78.3 \%$ of the subjects on whom this type of violence is perpetrated. More than half of these victims were in the knowledge branch of Social and Legal Sciences (52.2\%). Concerning the parents' level of education, there were hardly any significant differences between the father and mother; however, for $26.1 \%$ of victims of relational bullying, both parents had not completed their compulsory education. The figures for parents with only primary education-which includes uncompleted studies—stood at $52.2 \%$ for mothers and $47.8 \%$ for fathers, slightly higher than those recorded by the INE (Instituto Nacional de Estadística) for Spain as a whole [113].

Table 2. Profile of relational victimization in university students (in percentages).

\begin{tabular}{|c|c|c|c|c|c|}
\hline & Woman & Man & & & \\
\hline \multirow[t]{2}{*}{ Gender } & 78.3 & 21.7 & & & \\
\hline & Arts and Humanities & Sciences & Health Sciences & $\begin{array}{l}\text { Social and Legal } \\
\text { Sciences }\end{array}$ & $\begin{array}{c}\text { Engineering and } \\
\text { Architecture }\end{array}$ \\
\hline \multirow[t]{2}{*}{ Knowledge Branch } & 30.4 & 4.3 & 8.7 & 52.2 & 4.3 \\
\hline & $<$ Basic Level & Basic & Secondary & Higher & \\
\hline Mother's Studies & 26.1 & 26.1 & 30.4 & 17.4 & \\
\hline \multirow[t]{2}{*}{ Father's Studies } & 26.1 & 21.7 & 30.4 & 21.7 & \\
\hline & Employed & Unemployed & Inactive & & \\
\hline Mother's Job & 52.2 & 0 & 47.8 & & \\
\hline Father's Job & 69.6 & 4.3 & 25.8 & & \\
\hline School Violence & Yes & No & & & \\
\hline Physical & 21.7 & 78.3 & & & \\
\hline Relational & 87.0 & 13.0 & & & \\
\hline Verbal & 82.6 & 17.4 & & & \\
\hline
\end{tabular}

Regarding the relationship between parents and the labor market, there are differences between employment and inactivity. In this case, the former was greater among fathers and the latter was greater among mothers, in line with Spain's data [114]. Among those students who suffered relational victimization during their university years, it was found that $21.7 \%$ suffered prior physical victimization, $87.0 \%$ suffered prior relational victimization, and $82.6 \%$ suffered prior verbal victimization during their compulsory education.

Concerning university students who suffered verbal violence, the following results were obtained (see Table 3). First, as with relational victimization, there was an overdimensioning of women, accounting for $63.6 \%$ compared to $36.4 \%$ for men. For the branch 
of knowledge in which it occurs, we observed a distinction from relational victimization, since it was observed mainly in degrees related to the Arts and Humanities (45.5\%), followed by Social and Legal Sciences (36.4\%). Concerning the parents' academic training and their relationship with the labor market, we obtained data identical to those from students suffering relational victimization. Finally, an approximation was made of the victimization suffered during compulsory education by those currently suffering from relational violence: it was observed that $27.3 \%$ suffered from verbal violence, $81.1 \%$ suffered from relational violence, and a significant $90.9 \%$ suffered from verbal violence.

Table 3. Profile of verbal victimization in university students (in percentages).

\begin{tabular}{|c|c|c|c|c|c|}
\hline & Woman & Man & & & \\
\hline \multirow[t]{2}{*}{ Gender } & 63.6 & 36.4 & & & \\
\hline & Arts and Humanities & Sciences & Health Sciences & $\begin{array}{l}\text { Social and Legal } \\
\text { Sciences }\end{array}$ & $\begin{array}{l}\text { Engineering and } \\
\text { Architecture }\end{array}$ \\
\hline \multirow[t]{2}{*}{ Knowledge Branch } & 45.5 & 0 & 9.1 & 36.4 & 9.1 \\
\hline & $<$ Basic Level & Basic & Secondary & Higher & \\
\hline Mother's Studies & 26.1 & 26.1 & 30.4 & 17.4 & \\
\hline \multirow[t]{2}{*}{ Father's Studies } & 26.1 & 21.7 & 30.4 & 21.7 & \\
\hline & Employed & Unemployed & Inactive & & \\
\hline Mother's Job & 52.2 & 0 & 47.8 & & \\
\hline Father's Job & 69.6 & 4.3 & 25.8 & & \\
\hline School Violence & Yes & No & & & \\
\hline Physical & 27.3 & 72.7 & & & \\
\hline Relational & 81.8 & 18.2 & & & \\
\hline Verbal & 90.9 & 9.1 & & & \\
\hline
\end{tabular}

Later, a cross-table analysis was performed to observe the relationships between variables considering chi-square $p<0.005$. Taking relational victimization as a reference, associations were observed with the mother's work $(p=0.008)$, with having been a victim of physical violence at school $(p=0.020)$, with having been a victim of relational violence at school $(p=0.000)$, and with having been a victim of physical violence at school $(p=0.026)$. For verbal violence, there were relationships with having suffered violence at school in its three dimensions: physical $(p=0.026)$, relational $(p=0.002)$, and verbal $(0.001)$. In other words, both relational and verbal violence are mainly associated with suffering the different types of violence (physical, relational, and verbal) in a previous educational stage.

A binary logistic regression was performed to test the predictive variables of relational and verbal violence among university students. It was not done on physical violence because the descriptive analysis showed that this phenomenon does not occur in university students $(0 \%)$. The only model that showed robustness and reliability of results was that in which relational violence among university students was considered a dependent variable.

Binary logistic regression of relational violence in college students, showed in Table 4 , presented a statistically significant $\mathrm{X} 2=27.740, p<0.000$. The model explained $24.0 \%$ (Nagelkerke's R2) of moderately high consumption variance and correctly classified $90.7 \%$ of the cases. The Hosmer-Lemeshow test showed no significant differences between the observed and predicted results in the model with $p=0.720$. 
Table 4. Summary of the binary logistic regression model.

\begin{tabular}{|c|c|c|c|c|c|}
\hline \multicolumn{6}{|c|}{ Relational Violence among University Students } \\
\hline & \multirow{2}{*}{ B } & \multirow{2}{*}{ Sig. } & \multirow{2}{*}{$\operatorname{Exp}(B)$} & \multicolumn{2}{|c|}{ 95\% C.I. $\operatorname{Exp}(B)$} \\
\hline & & & & Lower & Superior \\
\hline Relational Violence at School & 2.688 & 0.000 & 14.697 & 4.051 & 53.314 \\
\hline Mother who did not complete basic education & 1.246 & 0.034 & 3.475 & 1.100 & 10.979 \\
\hline Constant & -4.227 & 0.000 & 0.015 & & \\
\hline
\end{tabular}

The two variables included in the equation were (a) the fact of having suffered relational violence at school and (b) the mother's educational level being below the basic educational stage. Regarding relational violence at school, the odds ratio (OR) was 14.697, IC95\% (4.051-53.314), $p=0.000$. The mother's educational level being below the basic educational stage showed an OR of 3.475, IC95\% (1.100-10.979), $p=0.034$. Thus, university students are 14 times more likely to suffer this type of violence if they were previously victims of relational violence during their compulsory education. Besides this, there is a predictive family variable in the phenomenon: when the mother's educational level does not reach the basic level. Thus, students whose mother did not finish compulsory education are up to 3 times more likely to suffer from relational violence than other students.

\section{Discussion}

Throughout the present research, several points were verified from the perspective of an exploratory study proposed as an approach to the problem of bullying in Spanish university classrooms today. The first of these is the absence of physical violence among university students, an issue which, if it occurs, could be considered a crime under Spanish law. Secondly, relational and physical violence reached prevalence rates of $8.7 \%$ and $4.2 \%$, respectively. These results are similar to those of other research conducted in the European context [62]. Although it may be thought that these percentages are very low, it should be noted that we are speaking of non-compulsory studies, where all students are over 18 years of age and are in the transition to adulthood. These behaviors contradict the principles that guide academic institutions and the most elementary democratic and coexistence values of our society.

A remarkable fact uncovered in the descriptive analysis is that relational violence mainly developed among those who study degrees related to Social and Legal Sciences, and verbal violence mainly developed among students of degrees related to the Arts and Humanities. University students studying degrees in Science, Health Sciences, and Engineering and Architecture did not show high victimization rates.

According to the data obtained, of the total number of university students who suffer relational victimization, $87.0 \%$ and $82.6 \%$ also suffered relational and verbal violence, respectively, during their compulsory education. Concerning the subjects who suffer verbal violence, $81.1 \%$ sustained relational violence and $90.9 \%$ suffered that of a verbal nature during compulsory education. Therefore, there is a perpetuation of victimization throughout the educational stages, an aspect that should alert both health and educational institutions.

On the other hand, the mother's relationship with the labor market was associated with relational violence. Here, the difference in the employment level of women is significant-almost 20 percentage points lower than that of men. Their inactivity level is a hallmark of the Spanish labor market [114] because of the different attribution of roles between men and women due to the sexual division of labor $[115,116]$. In other words, the socio-familial variables related to the training and development of occupations in the labor market may determine children's victimization. The influence of these variables is related to the reproduction of inequities within the educational system, a pattern that is repeated in many countries, as shown by numerous studies [117-121]. 
Furthermore, if we look at the profile of a person who suffers from bullying, from a gender perspective, they are primarily women. Men tend to take on the role of perpetrators of violence [122] and suffer on rare occasions. Of the total numbers of people who reported suffering relational and verbal violence, $78.3 \%$ and $63.6 \%$, respectively, were women. Therefore, a profile associated with gender-based bullying can be observed in the university setting, with women being over-represented, unlike what usually occurs in earlier educational stages [123].

This may allow us to explain the variation found in relational and verbal victimization according to the field of study, with significantly more occurring in the social and legal sciences, on the one hand, and the arts and humanities on the other. The student population's very structure in these branches, where women form a majority in the Spanish university system [124-127], probably explains this finding. At the international level, this is also the case in these branches $[128,129]$. According to statistics from the Ministry of Universities (Ministerio de Universidades) of Spain for the 2018/2019 academic year [130], in the social and legal sciences, $59.8 \%$ of enrolled students were women and $40.2 \%$ were men $(64.9 \%$ and $35.1 \%$ among graduates, respectively, in 2018), and in the arts and humanities, $61.6 \%$ were women and $38.4 \%$ were men (among graduates, $65.5 \%$ and $34.5 \%$ were women and men, respectively). In the university world, as women mainly suffer bullying, it would be more present in those branches where there is a higher percentage of women. In those branches shown, it is undoubtedly the most elevated, except for in the health sciences, where the study structure (organization, methodology, internships, etc.) is substantially different.

When we applied binary logistic regression to determine the risk of suffering from relational violence, the mother's work did not stand out as predictive, but the educational level of the mother, together with the fact of the student having suffered relational violence previously, resulted in an up to 14 times greater chance of violence than that for another person who did not suffer this type of violence in the compulsory educational stage. University students whose mothers did not complete compulsory education were found to be 3 times more likely to suffer from relational violence than those whose mothers completed higher education.

In this sense, relational violence occurs mainly because of two phenomena. First, by reproducing relational violence over time, a pattern of victimization is maintained and can become a profile established and settled in young people that continues into adulthood. Therefore, it has consequences not only in their personal, family, and social spheres but also in the workplace [131-138]. We call this phenomenon "the spiral of relational violence" in university students. Second, relational violence is conditioned by social origin aspects, both in the compulsory education stage and in the university stage. The absence of a minimum level of education in mothers-and not in fathers-acts as a determinant of relational violence, being an opposing cause. This is also the case with the social reproduction of poverty [139-141].

Traditional bullying exists in university classrooms, as do other types such as cyberbullying, as reflected in many studies [142-146]. The prevention of cyberbullying can be focused on media education $[147,148]$, although in higher education, it does not have the physical dimension that is usually developed in the compulsory education stage [149]. Victimization in universities is shown through relational and verbal violence. The consequences for the victims can be multiple, educational and social. Still, they can have repercussions on a health and psychological level that can lead to anxiety, insomnia, depression, attention deficit, hyperactivity, and even suicide [150-153]. Therefore, as in other countries, it is necessary to continue researching the behavior of aggressors and the responses provided by the institutions involved. This is fundamental to adopting prevention strategies for emotional and behavioral aspects in an academic setting $[47,154]$. In university students, support [63] is the main strategy to redirect this problem and seek a solution to aggressive behavior in the classroom.

Regarding limitations, this research was conditioned by the health crisis derived from the COVID-19 pandemic in Spain. The context of uncertainty experienced in the university 
world at the time of the fieldwork, with the need to adapt the method to virtual teaching in Spanish universities and the lack of physical presence, was a significant handicap to obtaining a larger sample. However, it was research programmed for that moment; the dates could not be changed because coordination was required far in advance with all the universities. The ethical protocols for those moments had been signed. Also, because women are greater represented in university studies in Spain, the sample was deficient in men, an element to be considered in future research.

However, as noted above, the situation did not affect responses; the influence was on the sample size, which has also occurred in many previously planned investigations that have been affected by the pandemic. Further, representation of the entire Spanish university system was not our primary goal. This study and its results suggest the need to continue investigating bullying among university students, primarily the phenomenon of "the spiral of relational violence", which opens the door to future research along this line.

\section{Conclusions}

Our work's goals were to carry out an exploratory study as an approach to the current situation of bullying in higher education in Spain, mainly focused on the concept of the spiral of violence. In this context, new results were obtained that can contribute to more excellent knowledge about bullying. It is essential to lay the foundations for reducing and eradicating this practice in university classrooms.

As we pointed out, this social problem not only affects students during their compulsory education stage but also transcends the university stage, especially relational and verbal violence. There is more significant detection, identification, and social condemnation and repulsion concerning physical violence, with it having no place in university classrooms.

Relational victimization, which manifests itself through defamation, social exclusion, or denigration, persists in the university environment. Moreover, it does so mainly because of a pattern of relational violence that is repeated from the compulsory education stage. This is a predictive variable of this type of violence. It constitutes what we call "the spiral of relational violence" - victimization which runs throughout the student's life with psychological repercussions that can continue into adulthood, especially in the workplace. Furthermore, mothers' low educational level is also a determining factor in predicting this social phenomenon, which should warn us about the need to continue investigating how family factors can condition students' victimization. Also, we should not ignore the analysis of "the feminization of relational and verbal victimization" since it is women who, by far, more often suffer these types of violence.

We believe that this empirical research may offer practical implications for the educational community and government institutions, since bullying is a social problem that persists throughout the academic stages. For this reason, all the administrations involved must take part in tackling this problem, including university institutions, as they are a space where relational and verbal violence continues to occur. Some of these measures could be raising awareness among students from the early educational stages to the university stage, establishing psychosocial support services, promoting actions that allow the identification of these forms of violence, encouraging intervention with those who voluntarily value their aggressive behavior, etc.

This study makes up, above all, a first approach to what we consider "the spiral of relational violence". However, it provides a basis for approaching this phenomenon from a comprehensive and multidisciplinary perspective in Spanish universities. A future line of research would be to carry out a much larger study, representing many more universitiesif possible, all of them - and students surveyed, to give us an overview of the situation in Spain of this problem in higher education.

On the other hand, it would be imperative to examine another social problem related to bullying: hazing. This practice, which is a type of violence for many young people, primarily because of the humiliation and indignities it involves, is still present in many Spanish university centers, being carried out by students in their last years towards new- 
comers. On more than a few occasions-which is a sign of incomprehension of what bullying means in all its dimensions-it occurs with university institutions' permissiveness. Hazing rituals are alluded to as ancient, deeply rooted traditions and are even considered rites of passage or confraternity $[154,155]$. Still, most of the forms they take in Spain are unacceptable in 21st-century society. Although several studies have been conducted in neighboring Portugal $[156,157]$, current research in the Spanish context is practically non-existent, which opens up an urgent and necessary future research line.

Author Contributions: Conceptualization, J.G.-G., C.L.-P., J.Á.M.-L.; methodology, J.G.-G., C.L.-P., J.Á.M.-L.; validation, J.G.-G., C.L.-P., J.Á.M.-L.; formal analysis, J.G.-G., C.L.-P., J.Á.M.-L.; investigation, J.G.-G., C.L.-P., J.Á.M.-L.; data curation, J.G.-G., C.L.-P., J.Á.M.-L.; writing-original draft preparation, J.G.-G., C.L.-P., J.Á.M.-L.; writing-review and editing, J.G.-G., C.L.-P., J.Á.M.-L.; supervision, J.G.-G., C.L.-P., J.Á.M.-L.; project administration, J.G.-G., C.L.-P., J.Á.M.-L. All authors have read and agreed to the published version of the manuscript.

Funding: This research received no external funding.

Institutional Review Board Statement: The study was conducted according to the guidelines of the Declaration of Helsinki.

Informed Consent Statement: Informed consent was obtained from all subjects involved in the study.

Data Availability Statement: Data available on request due to privacy and ethical restrictions. Primary data are contained within the article.

Acknowledgments: We would like to thank all the students for their research participation, especially for their time and dedication to such a delicate and essential subject. This high interest allowed us to carry out the fieldwork with the maximum rigor and objectivity fundamental for this research.

Conflicts of Interest: The authors declare no conflict of interest.

\section{References}

1. Official Journal of the European Union. Information from European Union Institutions and Bodies. Council Conclusions of 12 May 2009 on a Strategic Framework for European Cooperation in Education and Training; EUR-Lex: Brussels, Belgium, 2019.

2. World Health Organization. World Report on Violence and Health: Summary; WHO: Geneva, Switzerland, 2002.

3. Leroy, S.T.; Copeland, W.E.; Costello, E.J.; Wolke, D. Adult mental health consequences of peer bullying and maltreatment in childhood: Two cohorts in two countries. Lancet Psychiatry 2015, 2, 524-531. [CrossRef]

4. Ruiz, M.; Rodriguez, R.; Llanes, C.; Blanco, C. Acoso escolar. Atención Primaria 2019, 51, 198-199. [CrossRef] [PubMed]

5. Beckley, A.L.; Caspi, A.; Arseneault, L.; Barnes, J.C.; Fisher, H.L.; Harrington, J.C.; Moffitt, T.E. The developmental nature of the victim-offender overlap. J. Dev. Life Course Criminol. 2018, 4, 24-49. [CrossRef] [PubMed]

6. Hoffman, C.Y.; Phillips, M.D.; Daigle, L.E.; Turner, M.G. Adult consequences of bully victimization: Are children or adolescents more vulnerable to the victimization experience? Youth Violence Juv. Justice 2017, 15, 441-464. [CrossRef]

7. Pabón, M.; Ramírez, L.; Jiménez, N.; Ponce, J.A.; Martínez, J.M.; Martos, R. Influence of personality traits and its interaction with the phenomenon of bullying: Multi-centre descriptive study. Int. J. Environ. Res. Public Health 2020, $17,172$.

8. Smith, P.K. Bullying in schools: Lessons from two decades of research. Aggress. Behav. 2000, 26, 9. [CrossRef]

9. Volk, A.; Dane, A.V.; Marini, Z.A. What is bullying? A theoretical redefinition. Dev. Rev. 2014, 34, 327-343. [CrossRef]

10. Smith, P.; Sharp, S. School Bullying: Insights and Perspectives; Routledge: London, UK, 1994.

11. Johnson, E.J. An exploratory study on the prevention of school children from violence and abuse. J. Hum. Behav. Soc. Environ. 2020, 30, 399-409. [CrossRef]

12. Arce, R.; Velasco, J.; Novo, M.; Fariña, F. Elaboración y validación de una escala para la evaluación del acoso escolar. Rev. Iberoam. Psicol. Salud 2014, 5, 71-104.

13. Olweus, D. Familial and temperamental determinants of aggressive behavior in adolescent boys: A causal analysis. Dev. Psychol. 1983, 16, 644-660. [CrossRef]

14. Avilés, J.M. Victimización percibida y bullying. Factores diferenciales entre víctimas. Boletín Psicol. 2009, 95, 7-28.

15. Vilariño, M.; Fariña, F.; Arce, R. Discriminating real victims from feigners of psychological injury in gender violence: Validating a protocol for forensic settings. Eur. J. Psychol. Appl. Leg. Context 2009, 1, 221-243.

16. Novo, M.; Seijo, D.; Vilariño, M.; Vázquez, M.J. Frecuencia e Intensidad en el Acoso Escolar: ¿Qué es qué en la victimización? Rev. Iberoam. Psicol. Salud 2013, 4, 1-15.

17. Equipo Lisis. Escala de Victimización en la Escuela. 2004. Available online: http:/ / www.uv.es/lisis/ (accessed on 19 September 2020).

18. UNESCO. Behind the Numbers: Ending School Violence and Bullying; UNESCO: Paris, France, 2019. 
19. Golmaryami, F.N.; Frick, P.J.; Hemphill, S.A.; Kahn, R.E.; Crapanzano, A.M.; Terranova, A.M. The social, behavioral, and emotional correlates of bullying and victimization in a school-based sample. J. Abnorm. Child Psychol. 2016, 44, 381-391. [CrossRef]

20. Randa, R.; Reyns, B.W.; Nobles, M.R. Measuring the effects of limited and persistent school bullying victimization: Repeat victimization, fear, and adaptive behaviors. J. Interpers. Violence 2019, 34, 392-415. [CrossRef] [PubMed]

21. Marcos, V.; Gancedo, Y.; Selaya, A.; Novo, M. Analyzing the path from bullying to bully. In 2019 Annual Conference of the European Association of Psychology and Law; Sanmarco, J., Arias, E., Eds.; European Association of Psychology and Law: Santiago de Compostela, Spain, 2019; p. 165.

22. Moreno, D.; Estévez, E.; Murgui, S.; Musitu, G. Relación entre el clima familiar y el clima escolar: El rol de la empatía, la actitud hacia la autoridad y la conducta violenta en la adolescencia. Int. J. Psychol. Psychol. 2009, 9, 123-136.

23. Stephens, M.M.; Cook-Fasano, H.T.; Sibbaluca, K. Childhood bullying: Implications for physicians. Am. Fam. Physician 2018, 97, 187-192.

24. Ronksley-Pavia, M.; Grootenboer, P.; Pendergast, D. Bullying and the unique experiences of twice-exceptional learners: Student perspective narratives. Gift. Child Today 2019, 42, 19-35. [CrossRef]

25. Smith, A.U.; Norris, A.E. Parent communication and bullying among Hispanic adolescent girls. J. Sch. Nurs. 2020, 36, 222-232. [CrossRef]

26. Wiebush, R.; Freitag, R.; Baird, C. Preventing Delinquency through Improved Child Protective Services; OJJDP Juvenile Justice Bulleting, Department of Justice, Office of Juvenile Justice and Delinquency Prevention: Washington, DC, USA, 2001.

27. Shaffer, J.N.; Ruback, R.B. Violent Victimization as a Risk Factor for Violent Offending among Juveniles; OJJDP Juvenile Justice Bulleting, Department of Justice, Office of Juvenile Justice and Delinquency Prevention: Washington, DC, USA, 2002.

28. Smokowski, P.R.; Kopasz, K.H. Bullying in school: An overview of types, effects, family characteristics, and intervention strategies Child. Sch. 2005, 27, 101-110. [CrossRef]

29. Estévez, E.; Jiménez, T.I.; Moreno, D.; Musitu, G. An analysis of the relationship between victimization and violent behavior at school. Span. J. Psychol. 2013, 16, e22.

30. Walters, G.D.; Espelage, D.L. From victim to victimizer: Hostility, anger, and depression as mediators of the bullying victimizationbullying perpetration association. J. Sch. Psychol. 2018, 68, 73-83. [CrossRef] [PubMed]

31. Kim, Y.S.; Koh, Y.J.; Leventhal, B. School bullying and suicidal risk in Korean middle school students. Pediatrics 2005, 115, 357-363. [CrossRef]

32. Posner, K.; Melvin, G.A.; Stanley, B.; Oquendo, M.A.; Gould, M. Factors in the assessment of suicidality in youth. CNS Spectr. 2007, 12, 156-162. [CrossRef]

33. Klimek, A.B.; Sourander, A.; Gould, M. The association of suicide and bullying in childhood to young adulthood: A review of cross-sectional and longitudinal research findings. Can. J. Psychiatry 2010, 55, 282-288. [CrossRef]

34. Hawton, K.; Saunders, K.E.; O'Connor, R.C. Self-harm and suicide in adolescents. Lancet North Am. Ed. 2012, 379, 2373-2382. [CrossRef]

35. Kokkevi, A.; Rotsika, V.; Aragaki, A.; Richardson, C. Adolescents' self-reported suicide attempts, self-harm thoughts and their correlates across 17 European countries. J. Child Psychol. Psychiatry 2012, 53, 381-389. [CrossRef]

36. Nock, M.K.; Green, J.G.; Hwang, I.; McLaughlin, K.A.; Sampson, N.A.; Zaslavsky, A.M.; Kessler, R.C. Prevalence, correlates, and treatment of lifetime suicidal behavior among adolescents: Results from the National Comorbidity Survey Replication Adolescent Supplement. JAMA Psychiatry 2013, 70, 300-310. [CrossRef]

37. Van Geel, M.; Vedder, P.; Tanilon, J. Relationship between peer victimization, cyberbullying, and suicide in children and adolescents: A meta-analysis. JAMA Pediatrics 2014, 168, 435-442. [CrossRef]

38. Rhodes, A.E.; Boyle, M.H.; Bridge, J.A.; Sinyor, M.; Links, P.S.; Tonmyr, L.; Skinner, R.; Bethell, J.M.; Carlisle, C.; Goodday, S.; et al. Antecedents and sex/gender differences in youth suicidal behavior. World J. Psychiatry 2014, 4, 120. [CrossRef]

39. Alavi, N.; Roberts, N.; Sutton, C.; Axis, N.; Repetti, L. Bullying victimization (being bullied) among adolescents referred for urgent psychiatric consultation: Prevalence and association with suicidality. Can. J. Psychiatry 2015, 60, 427-431. [CrossRef]

40. Klimek, A.B.; Sourander, A.; Elonheimo, H. Bullying by peers in childhood and affects on psychopathology, suicidality, and criminality in adulthood. Lancet Psychiatry 2015, 2, 844-855.

41. McKinnon, B.; Gariépy, G.; Sentenac, M.; Elgar, F.J. Adolescent suicidal behaviours in 32 low-and middle-income countries. Bull. World Health Organ. 2016, 94, 340. [CrossRef]

42. Asante, K.O.; Kugbey, N.; Osafo, J.; Quarshie, E.N.B.; Sarfo, J.O. The prevalence and correlates of suicidal behaviours (ideation, plan and attempt) among adolescents in senior high schools in Ghana. Ssm-Popul. Health 2017, 3, 427-434. [CrossRef]

43. Barzilay, S.; Klimek, A.B.; Apter, A.; Carli, V.; Wasserman, C.; Hadlaczky, G.; Brunner, R. Bullying victimization and suicide ideation and behavior among adolescents in Europe: A 10-country study. J. Adolesc. Health 2017, 61, 179-186. [CrossRef]

44. Sigurdson, J.F.; Undheim, A.M.; Wallander, J.L.; Lydersen, S.; Sund, A.M. The longitudinal association of being bullied and gender with suicide ideations, self-harm, and suicide attempts from adolescence to young adulthood: A cohort study. Suicide Life-Threat. Behav. 2018, 48, 169-182. [CrossRef]

45. Koyanagi, A.; Oh, H.; Carvalho, A.F.; Smith, L.; Haro, J.M.; Vancampfort, D.; DeVylder, J.E. Bullying victimization and suicide attempt among adolescents aged 12-15 years from 48 countries. J. Am. Acad. Child Adolesc. Psychiatry 2019, 58, 907-918. [CrossRef]

46. Zebadúa, E. Editorial: Carta del director. Rev. AZ 2010, 34, 3-4. 
47. Millan, L.C.; Barrera, L.F.; Ospina, J.M. Caracterización del bullying en estudiantes de medicina de Tunja. Boyacá. Rev. Virtual Univ. Católica Del Norte 2015, 45, 101-112.

48. Blanco, J.; Caso, A.M.; Navas, G. Violencia escolar: Cyber-bullying en redes sociales. Int. J. Dev. Educ. Psychol. 2012, 1, 717-724.

49. Flaspohler, P.D.; Elfstrom, J.L.; Vanderzee, K.L.; Sink, H.E.; Birchmeier, Z. Stand by me: The effects of peer and teacher support in mitigating the impact of bullying on quality of life. Psychol. Sch. 2009, 46, 636-649. [CrossRef]

50. Chocarro, E.; Garaigordobil, M. Bullying and cyberbullying: Sex differences in victims, aggressors and observers. Pensam. Psicológico 2019, 17, 57-71. [CrossRef]

51. González, F.; Guillén, F.D.; Castro, R.M. Methodological analysis of the effect of an anti-bullying programme in secondary education through communicative competence: A pre-test-post-test study with a control-experimental group. Int. J. Environ. Res. Public Health 2020, 17, 3047. [CrossRef]

52. Íñiguez, T.; Cano, J.; Cortés, A.; Elboj, C. Structural model of concurrence among relational bullying and cyberbullying: Victims, aggressors and bystanders. Rev. Española Investig. Sociológicas 2020, 171, 63-84.

53. Salmivalli, C.; Lagerspetz, K.; Björkqvist, K.; Österman, K.; Kaukiainen, A. Bullying as a group process: Participant roles and their relations to social status within the group. Aggress. Behav. Off. J. Int. Soc. Res. Aggress. 1996, 22, 1-15. [CrossRef]

54. Demaray, M.K.; Summers, K.H.; Jenkins, L.N.; Becker, L.D. Bullying Participant Behaviors Questionnaire (BPBQ): Establishing a reliable and valid measure. J. Sch. Violence 2016, 15, 158-188. [CrossRef]

55. Alcántar, C.; Valdés, A.A.; Martínez, E.A.; Martínez, B.; García-Vázquez, F.I. Propiedades Psicométricas de la Adaptación al Español de la Participant Role Approach (PRA). Rev. Colomb. Psicol. 2018, 27, 177-192. [CrossRef]

56. García-Vázquez, F.I.; Valdés, A.A.; Martínez-Ferrer, B.; Parra, L.G. Forgiveness, gratitude, happiness, and prosocial bystander behavior in bullying. Front. Psychol. 2020, 10, 2827. [CrossRef]

57. Salmivalli, C.; Voeten, M.; Poskiparta, E. Bystanders matter: Associations between reinforcing, defending, and the frequency of bullying behavior in classrooms. J. Clin. Child Adolesc. Psychol. 2011, 40, 668-676. [CrossRef]

58. Williford, A.; Boulton, A.; Noland, B.; Little, T.D.; Kärnä, A.; Salmivalli, C. Effects of the KiVa anti-bullying program on adolescents' depression, anxiety, and perception of peers. J. Abnorm. Child Psychol. 2012, 40, 289-300. [CrossRef]

59. Gaffney, H.; Farrington, D.P.; Ttofi, M.M. Examining the effectiveness of school-bullying intervention programs globally: A meta-analysis. Int. J. Bullying Prev. 2019, 1, 14-31. [CrossRef]

60. Goldberg, J.M.; Sklad, M.; Elfrink, T.R.; Schreurs, K.M.; Bohlmeijer, E.T.; Clarke, A.M. Effectiveness of interventions adopting a whole school approach to enhancing social and emotional development: A meta-analysis. Eur. J. Psychol. Educ. 2019, 34, 755-782. [CrossRef]

61. Tiiri, E.; Luntamo, T.; Mishina, K.; Sillanmäki, L.; Klimek, A.B.; Sourander, A. Did bullying victimization decrease after nationwide school-based antibullying program? A time-trend study. J. Am. Acad. Child Adolesc. Psychiatry 2020, 59, 531-540. [CrossRef]

62. Sinkkonen, H.M.; Puhakka, H.; Meriläinen, M. Bullying at a university: Students' experiences of bullying. Stud. High. Educ. 2014, 39, 153-165. [CrossRef]

63. Meriläinen, M.; Puhakka, H.; Sinkkonen, H.M. Students' suggestions for eliminating bullying at a university. Br. J. Guid. Couns. 2015, 43, 202-215. [CrossRef]

64. McKennie, S.W. A Phenomenological Study of College Students Subjected to Cyberbullying. Ph.D. Thesis, Northcentral University, Scottsdale, AZ, USA, 2017.

65. Souza, S.B.; Veiga Simão, A.M.; Ferreira, A.I.; Ferreira, P.C. University students' perceptions of campus climate, cyberbullying and cultural issues: Implications for theory and practice. Stud. High. Educ. 2018, 43, 2072-2087. [CrossRef]

66. Méndez, I.; Ruiz-Esteban, C.; Martínez, J.P.; Cerezo, F. Acoso escolar en el ámbito universitario. Psicol. Conduct. 2019, 27, 55-68.

67. Walls-Pickett, A.D. Bullying on a College Campus: A Qualitative Study. Ph.D. Thesis, Walden University, Minneapolis, MN, USA, 2019.

68. Martínez, J.P.; Méndez, I.; Ruiz, C.; Cerezo, F. Validación y fiabilidad del Cuestionario sobre Acoso entre Estudiantes Universitarios (QAEU). Rev. Fuentes 2020, 22, 88-104. [CrossRef]

69. Royo-García, P.; Gutiérrez, C.L.; Giménez, M.; Serrano, C. ¿Existe el bullying en la universidad? Aproximación a esta realidad con una muestra española de estudiantes de grado. Edetania. Estud. Propues. Socioeducativas 2020, 57, 85-109. [CrossRef]

70. Myers, C.A.; Cowie, H. University students' views on bullying from the perspective of different participant roles. Pastor. Care Educ. 2013, 31, 251-267. [CrossRef]

71. Silva, A.C.; Farhangmehr, M.; Jalali, M.S. License to bully: Rites of passage in higher education. Int. Rev. Public Nonprofit Mark. 2018, 15, 49-66. [CrossRef]

72. Coleyshaw, L. The power of paradigms: A discussion of the absence of bullying research in the context of the university student experience. Res. Post-Compuls. Educ. 2010, 15, 377-386. [CrossRef]

73. Magner, K. Is Drama the New Bullying? Differentiating Bullying and Drama among College Students. Ph.D. Thesis, Carleton University, Ottawa, ON, Canada, 2019.

74. Harrison, E.D. Exploring Student Victimisation and Wellbeing in the UK Higher Education Context. Ph.D. Thesis, Keele University, Keele, Newcastle, UK, 2020.

75. Cowie, H.; Myers, C.A. Bullying among University Students: Cross-National Perspectives; Routledge: London, UK, 2015.

76. Colleyshaw, E. An Examination of Bullying in Different Institutional Contexts: Undergraduate Student Notions of Bullying in the School, the Workplace and University. Ph.D. Thesis, University of Wolverhampton, Wolverhampton, UK, 2015. 
77. Merry, L.; Royce-Davis, J. Looking to the future-Exploring the need to address bullying in higher education. In Students, Teachers, and Leaders Addressing Bullying in Schools; Boske, C., Osanloo, A., Eds.; Sense Publishers: Rotterdam, The Netherlands, 2015; pp. 199-217.

78. Vveinhardt, J.; Fominiene, V.B.; Andriukaitiene, R.; Streimikiene, D. Harassment and bullying among students in higher education institutions: Manifestation of single cases of harassment and bullying in aspects of demographic variables. Amfiteatru Econ. J. 2019, 21, 409. [CrossRef]

79. Bibi, A.; Blackwell, S.E.; Margraf, J. Mental health, suicidal ideation, and experience of bullying among university students in Pakistan. J. Health Psychol. 2019. online ahead of print. [CrossRef]

80. Wang, G.F.; Han, A.Z.; Zhang, G.B.; Xu, N.; Xie, G.D.; Chen, L.R.; Su, P.Y. Sensitive periods for the effect of bullying victimization on suicidal behaviors among university students in China: The roles of timing and chronicity. J. Affect. Disord. 2020, 268, 12-19. [CrossRef]

81. Pörhölä, M.; Cvancara, K.; Kaal, E.; Kunttu, K.; Tampere, K.; Torres, M.B. Bullying in university between peers and by personnel: Cultural variation in prevalence, forms, and gender differences in four countries. Soc. Psychol. Educ. 2020, 23, 143-169. [CrossRef]

82. Lin, M.; Wolke, D.; Schneider, S.; Margraf, J. Bullying history and mental health in university students: The mediator roles of social support, personal resilience, and self-efficacy. Front. Psychiatry 2020, 10, 960. [CrossRef]

83. Turan, N.; Polat, O.; Karapirli, M.; Uysal, C.; Turan, S.G. The new violence type of the era: Cyber bullying among university students: Violence among university students. Neurol. Psychiatry Brain Res. 2011, 17, 21-26. [CrossRef]

84. Xiao, B.S.; Wong, Y.M. Cyber-Bullying Among University Students: An Empirical Investigation from the Social Cognitive Perspective. Int. J. Bus. Inf. 2013, 8, 34.

85. Cowie, H.; Myers, C.A. What do we know about bullying and cyberbullying among university students. In Bullying among University Students: Cross-National Perspectives; Cowie, H., Myers, C.A., Eds.; Routledge: New York, NY, USA, 2016; pp. 3-14.

86. Kokkinos, C.M.; Baltzidis, E.; Xynogala, D. Prevalence and personality correlates of Facebook bullying among university undergraduates. Comput. Hum. Behav. 2016, 55, 840-850. [CrossRef]

87. Byers, D.S.; Cerulli, M. Staying in their own lane: Ethical reasoning among college students witnessing cyberbullying. J. Divers. High. Educ. 2020. [CrossRef]

88. Wensley, K.; Campbell, M. Heterosexual and nonheterosexual young university students' involvement in traditional and cyber forms of bullying. Cyberpsychology Behav. Soc. Netw. 2012, 15, 649-654. [CrossRef]

89. Mace, S.; Campbell, M.; Whiteford, C. Coping with victimization in heterosexual and sexual minority university students. J. Gay Lesbian Soc. Serv. 2016, 28, 159-170. [CrossRef]

90. Fuentes Cabrera, A.; Moreno-Guerrero, A.J.; Pozo-Sánchez, J.S.; Rodríguez-García, A.M. Bullying among teens: Are ethnicity and race risk factors for victimization? A bibliometric research. Educ. Sci. 2019, 9, 220. [CrossRef]

91. Harrison, E.D.; Hulme, J.A.; Fox, C.L. A thematic analysis of students' perceptions and experiences of bullying in UK higher education. Eur. J. Psychol. 2021. [CrossRef]

92. Kowalski, R.M.; Foster, M.; Scarborough, M.; Bourque, L.; Wells, S.; Graham, R.; Bednar, H.; Franchi, M.; Nash, S.; Crawford, K. Hazing, bullying, and moral disengagement. Int. J. Bullying Prev. 2020. [CrossRef]

93. Sperry, L. Mobbing and bullying: The influence of individual, work group, and organizational dynamics on abusive workplace behavior. Consult. Psychol. J. Pr. Res. 2009, 61, 190. [CrossRef]

94. Branch, S.; Ramsay, S.; Barker, M. Workplace bullying, mobbing and general harassment: A review. Int. J. Manag. Rev. 2013, 15, 280-299. [CrossRef]

95. Görgülü, N.; Beydağ, K.D.; Şensoy, F.; Kıyak, M. The effects of mobbing (bullying) on health employes. Procedia Soc. Behav. Sci. 2014, 152, 503-509. [CrossRef]

96. Einarsen, S. The nature and causes of bullying at work. Int. J. Manpow. 1999, 20, 16-27. [CrossRef]

97. Maran, D.A.; Bernardelli, S.; Varetto, A. Mobbing (bullying at work) in Italy: Characteristics of successful court cases. J. Inj. Violence Res. 2018, 10, 17.

98. Felix, R.O.; García-Hernandez, C.; Campos, N.H. Theoretical review of mobbing: Definitions, impact, and models. Enseñanza Investig. Psicol. 2018, 23, 20-29.

99. Yamada, D.C.; Duffy, M.; Berry, P.A. Workplace bullying and mobbing: Definitions, terms, and when they matter. In Workplace Bullying and Mobbing in the United States; Duffy, M., Yamada, D.C., Eds.; Praeger Publishers: Santa Barbara, CA, USA, 2018; Volume 1, pp. 3-24.

100. Bucci, L. Violencia Laboral. Mobbing: Víctimas Victimizadas; Editorial Autores de Argentina: Buenos Aires, Argentina, 2021.

101. Pheko, M.M. Autoethnography and cognitive adaptation: Two powerful buffers against the negative consequences of workplace bullying and academic mobbing. Int. J. Qual. Stud. Health Well-Being 2018, 13, 1459134. [CrossRef]

102. Mannix-McNamara, P. The contested terrain of power in workplace bullying. In Pathways of Job-Related Negative Behaviour. Handbooks of Workplace Bullying, Emotional Abuse and Harassment; D'Cruz, P., Noronha, E., Baillien, E., Catley, B., Harlos, K., Hogh, A., Mikkelsen, E.G., Eds.; Springer: Singapore, 2021; Volume 2, pp. 49-72.

103. Vaill, Z.; Campbell, M.; Whiteford, C. Analysing the quality of Australian universities' student anti-bullying policies. High. Educ. Res. Dev. 2020, 39, 1262-1275. [CrossRef]

104. Barratt-Pugh, L.G.; Krestelica, D. Bullying in higher education: Culture change requires more than policy. Perspect. Policy Pract. High. Educ. 2019, 23, 109-114. [CrossRef] 
105. Idsoe, T.; Vaillancourt, T.; Dyregrov, A.; Hagen, K.A.; Ogden, T.; Nærde, A. Bullying victimization and trauma. Front. Psychiatry 2021, 11, 1602. [CrossRef]

106. Cowie, H.; Myers, C.A. School Bullying and Mental Health: Risks, Intervention and Prevention; Routledge: New York, NY, USA, 2017.

107. Mynard, H.; Joseph, S. Development of the multidimensional peer-victimization scale. Aggress. Behav. 2000, $26,169-178$. [CrossRef]

108. Crick, R.N.; Grotpeter, J.K. Children's treatment by peers: Victims of relational and overt aggression. Dev. Psychopathol. 1996, 8, 367-380. [CrossRef]

109. López Pérez, M. Validación de un instrumento para medir el acoso escolar en estudiantes mexicanos. Enseñanza Investig. Psicol. 2016, 21, 291-299.

110. Vila, R.; Rubio, M.J.; Berlanga, V.; Torrado, M. Applying a hierarchical cluster SPSS. Rev. D'innovació Recer. Educ. $2014,7,113$.

111. Berlanga, V.; Vila, R. How to get a Binary Logistic Regression Model with SPSS. Rev. D'innovació Recer. Educ. $2014,7,105$.

112. Chatterjee, S.; Hadi, A.S. Regression Analysis by Example; John Wiley \& Sons: Hoboken, NJ, USA, 2015.

113. INE. Máximo Nivel Educativo Alcanzado Por las Personas Entre 18 y 65 Años Según Sexo y Grupo de Edad; Instituto Nacional de Estadística: Madrid, Spain, 2020; Available online: https: / / cutt.ly/vfJVC8H (accessed on 28 January 2021).

114. INE. Encuesta de Población Activa; Instituto Nacional de Estadística: Madrid, Spain, 2020; Available online: https:/ /cutt.ly/ifjBlZc (accessed on 28 January 2021).

115. Martínez-López, J.A.; Frutos, L.; Solano, J.C. Los usos de las prestaciones económicas de la dependencia en el municipio de Murcia. Un estudio de caso. Res. Rev. Española De Sociol. 2017, 26, 97-113. [CrossRef]

116. Martínez-López, J.A.; Frutos, L.; Solano, J.C. El Trabajo de Cuidados en el Sistema de la Dependencia; Tirant lo Blanch: Valencia, Spain, 2019.

117. Nordhagen, R.; Nielsen, A.; Stigum, H.; Köhler, L. Parental reported bullying among Nordic children: A population-based study. Child: Carehealth Dev. 2005, 31, 693-701. [CrossRef] [PubMed]

118. Mishna, F.; Scarcello, I.; Pepler, D.; Wiener, J. Teachers' understanding of bullying. Can. J. Educ. 2005, 28, 718-738. [CrossRef]

119. Holt, M.K.; Kaufman, G.; Finkelhor, D. Parent/child concordance about bullying involvement and family characteristics related to bullying and peer victimization. J. Sch. Violence 2008, 8, 42-63. [CrossRef]

120. Hoskins, B.; Janmaat, J.G.; Han, C.; Muijs, D. Inequalities in the education system and the reproduction of socioeconomic disparities in voting in England, Denmark and Germany: The influence of country context, tracking and self-efficacy on voting intentions of students age 16-18. Comp. J. Comp. Int. Educ. 2016, 46, 69-92. [CrossRef]

121. Bully, P.; Jaureguizar, J.; Bernard, E.; Redondo, I. Relationship between parental socialization, emotional symptoms, and academic performance during adolescence: The influence of parents' and teenagers' gender. Int. J. Environ. Res. Public Health 2019, 16, 2231. [CrossRef]

122. Stoudt, B.G. From the top on down it is systemic: Bullying, privilege and the schooling of hegemonic masculinity. Boyhood Stud. 2012, 6, 17-33. [CrossRef]

123. Iossi, M.A.; Pereira, B.; Mendonça, D.; Nunes, B.; Oliveira, W.A. The involvement of girls and boys with bullying: An analysis of gender differences. Int. J. Environ. Res. Public Health 2013, 10, 6820-6831. [CrossRef]

124. López-Sáez, M.; Morales, J.M.; Lisbona, A.M. Evolution of Gender Stereotypes in Spain: Traits and Roles. Span. J. Psychol. 2008, 11, 609-617. [CrossRef]

125. Chivite, M.J.; Hernández, M.B.; Monzón, M.E. Frontera y Género. En los Límites de la Multidisciplinariedad; Plaza y Valdés: Madrid, Spain, 2011.

126. Instituto de la Mujer. Mujeres en Cifras. Educación. Alumnado Universitario; Instituto de la Mujer: Madrid, Spain, 2016.

127. Sáinz, M.; Castaño, C.; Meneses, J.; Fàbregues, S.; Müller, J.; Rodó, M.; Martínez, J.L.; Romano, M.J.; Arroyo, L.; Garrido, N. ¿Por Qué no Hay Más Mujeres STEM? Se Buscan Ingenieras, Físicas y Tecnólogas; Ariel: Madrid, Spain, 2017.

128. Steele, C.M. A threat in the air: How stereotypes shape intellectual identity and performance. Am. Psychol. 1997, 52, 613-629. [CrossRef]

129. Ceci, S.J.; Williams, W.M. Why Aren't More Women in Science? Top Research Debate the Evidence; American Psychological Association: Washington, DC, USA, 2007.

130. Ministerio de Universidades. Datos y Cifras del Sistema Universitario Español. Publicación 2019-2020; Ministerio de Universidades: Madrid, Spain, 2020.

131. Mora, J.A. Las estrategias de afrontamiento, ¿mediadoras de los efectos a largo plazo de las víctimas del bullying? Anu. Psicol. Clínica Salud 2006, 2, 15-26.

132. Sanmartín, P.G. Bullying: Una puerta de entrada a la conducta antisocial adulta. Rev. Int. Politicas Bienestar Trab. Soc. 2019, 11, 151-202.

133. Caba, M.A.; López, R. La agresión entre iguales en la era digital: Estrategias de afrontamiento de los estudiantes del último ciclo de Primaria y del primero de Secundaria. Rev. Educ. 2013, 362, 247-272.

134. Yoo, G.; Lee, S. It doesn't end there: Workplace bullying, work-to-family conflict, and employee wellbeing in Korea. Int. J. Environ. Res. Public Health 2018, 15, 1548. [CrossRef]

135. Finstad, G.L.; Ariza, A.; Giorgi, G.; Lecca, L.I.; Arcangeli, G.; Mucci, N. The JDCS model and blue-collar bullying: Decent working conditions for a healthy environment. Int. J. Environ. Res. Public Health 2019, 16, 3411. [CrossRef] 
136. Chacón, R.; Epelde, A.; Oñederra, J. Trabajo colaborativo en el aula, bullying y cyberbullying: Estudio con adolescentes. Rev. Iberoam. De Psicol. 2019, 12, 1-8.

137. Vveinhardt, J.; Fominiene, V.B.; Andriukaitiene, R. Encounter with bullying in sport and its consequences for youth: Amateur athletes' approach. Int. J. Environ. Res. Public Health 2019, 16, 4685. [CrossRef]

138. Gil Villa, F. El Bullying que No Cesa: Las Bases de la Violencia Escolar; Ediciones Octaedro: Barcelona, Spain, 2020.

139. Martínez, J. Clase social, tipo de familia y logro educativo en Canarias. Papers. Rev. Sociol. 2008, 87, 77-100.

140. Valdés, M.T. Efectos primarios y secundarios del origen social en la transición a la educación posobligatoria en España. Rev. Española Investig. Sociológicas 2020, 171, 125-144.

141. Daza, L.; Troiano, H.; Marina, E.A. La transición a la universidad desde el bachillerato y desde el CFGS. La importancia de los factores socioeconómicos. Papers. Rev. Sociol. 2019, 1, 1-21.

142. Gómez-Galán, J. Educar en Nuevas Tecnologías y Medios de Comunicación; Fondo Educación CRE: Sevilla, Spain, 2003.

143. Wright, M.F.; Wachs, S. Does parental mediation moderate the longitudinal association among bystanders and perpetrators and victims of cyberbullying? Soc. Sci. 2018, 7, 231. [CrossRef]

144. Myers, C.A.; Cowie, H. Cyberbullying across the lifespan of education: Issues and interventions from school to university. Int. J. Environ. Res. Public Health 2019, 16, 1217. [CrossRef]

145. Graham, R.; Wood, F.R. Associations between cyberbullying victimization and deviant health risk behaviors. Soc. Sci. J. 2019, 56, 183-188. [CrossRef]

146. López-Meneses, E.; Vázquez-Cano, E.; González-Zamar, M.D.; Abad, E. Socioeconomic effects in cyberbullying: Global research trends in the educational context. Int. J. Environ. Res. Public Health 2020, 17, 4369. [CrossRef]

147. Gómez-Galán, J. Media education as theoretical and practical paradigm for digital literacy: An interdisciplinary analysis. Eur. J. Sci. Theol. 2015, 11, 31-44.

148. Gómez-Galán, J. Media education in the ICT era: Theoretical structure for innovative teaching styles. Information 2020, 11, 276. [CrossRef]

149. Song, M.; Zhu, Z.; Liu, S.; Fan, H.; Zhu, T.; Zhang, L. Effects of aggressive traits on cyberbullying: Mediated moderation or moderated mediation? Comput. Hum. Behav. 2019, 97, 167-178. [CrossRef]

150. Mills, C.; Guerin, S.; Lynch, F.; Daly, I.; Fitzpatrick, C. The relationship between bullying, depression and suicidal thoughts/behaviour in Irish adolescents. Ir. J. Psychol. Med. 2004, 21, 112-116. [CrossRef] [PubMed]

151. Lund, R.; Nielsen, K.K.; Hansen, D.H.; Kriegbaum, M.; Molbo, D.; Due, P.; Christensen, U. Exposure to bullying at school and depression in adulthood: A study of Danish men born in 1953. Eur. J. Public Health 2009, 19, 111-116. [CrossRef] [PubMed]

152. Hinduja, S.; Patchin, J.W. Connecting adolescent suicide to the severity of bullying and cyberbullying. J. Sch. Violence 2019, 18, 333-346. [CrossRef]

153. Chen, Y.L.; Ho, H.Y.; Hsiao, R.C.; Lu, W.H.; Yen, C.F. Correlations between quality of life, school bullying, and suicide in adolescents with attention-deficit hyperactivity disorder. Int. J. Environ. Res. Public Health 2020, 17, 3262. [CrossRef]

154. Kuester, N.M.; Souza, F.R.; Finkler, M. Social representations of college hazing: A necessary ethical reflection. Texto Contexto Enferm. 2019, 28, e20170359.

155. Salinas, C.; Boettcher, M.L. Critical Perspectives on Hazing in Colleges and Universities: A Guide to Disrupting Hazing Culture; Routledge: London, UK, 2018.

156. Silva, O.; Caldeira, S.N.; Mendes, M.; Botelho, S.P. Bullying in hazing practices: A study on higher education. In ICERI2014 Proceedings; Gómez, A., López, I., Candel, T., Eds.; IATED Academy: Seville, Spain, 2014; pp. 784-791.

157. Fávero, M.; Pinto, S.; Ferreira, F.; Machado, F.; Del Campo, A. Hazing violence: Practices of domination and coercion in hazing in Portugal. J. Interpers. Violence 2018, 33, 1830-1851. [CrossRef] 